\title{
PENGARUH POSISI KAS, RASIO UTANG TERHADAP EKUITAS,DAN POTENSI PERTUMBUHAN TERHADAP RASIO PEMBAGIAN DIVIDEN PADA PERUSAHAAN MANUFAKTUR YANG TERDAFTAR DI BEI
}

\author{
Indayani \& M. Nur Yahya \\ Fakultas Ekonomi Universitas Syiah Kuala
}

\begin{abstract}
The Effect of Cash Position, Debt to Equity Ratio and Growth's Potential to Dividen Pay-Out Ratio in Manufacturing Companies Listed in BEI. The aim of this study is to determine and examine the influence of cash position, debt to equity ratio, and growth potential to the dividend payout ratio of companies listed in Indonesia Stock Exchange (BEI). The analysis method of the data used to test the hypothesis is the multiple linear regressions. The test result showed that simultaneous cash position, debt to equity ratio, and growth potential did not significantly influence the dividend payout ratio at manufacturing companies listed on the BEI. The test results showed that only partially variable cash position that significantly influence the dividend payout ratio of companies listed on the Stock Exchange, while variable debt to equity ratio, and growth potential does not affect the dividend payout ratio of companies listed on the BEI
\end{abstract}

Keyword: dividend payout ratio, cash position, debt to equity ratio, growth's potential, regression

Abstrak. Pengaruh Posisi Kas, Rasio Utang Terhadap Ekuitas, dan Potensi Pertumbuhan Terhadap Rasio Pembagian Dividen Pada Perusahaan Manufaktur Yang Terdaftar di BEI. Tujuan dari kajian ini ialah untuk menentukan dan menguji pengaruh posisi kas, rasio utang terhadap ekuitas, dan potensi pertumbuhan terhadap rasio pembagian dividen dari perusahaan manufaktur yang terdaftar di BEI. Teknik analisis yang dipergunakan ialah regresi berganda. Hasil pengujian menunjukkan bahwa secara simultan posisi kas, rasio utang terhadap ekuitas, dan potensi pertumbuhan tidak berpengaruh terhadap rasio pembagian dividen pada perusahaan manufaktur di BEI. Hasil yang ada menunjukkan bahwa hanya variabel posisi kas saja yang memiliki pengaruh terhadap rasio pembagian dividen, sedangkan rasio utang terhadap ekuitas dan potensi pertumbuhan tidak memiliki pengaruh apapun terhadap rasio pembangian dividen.

Kata Kunci: rasio pembagian dividen, posisi kas, rasio utang terhadap ekuitas, potensi pertumbuhan, regresi 


\section{PENDAHULUAN}

Kebijakan bidang keuangan yang dijalankan perusahaan harus selaras dan serasi dengan tujuan maksimalisasi keuntungan yang merupakan tujuan utama dari perusahaan. Salah satu kebijakan yang utama untuk memaksimalisasi keuntungan perusahaan adalah kegiatan investasi. Dalam kegiatan investasi manajer harus mengalokasikan dana ke dalam bentuk investasi yang dapat menghasilkan keuntungan di masa depan. Dalam kegiatan investasi tersebut perlu mempertimbangkan sumber pendanaan investasi tersebut apakah dari sumber internal atau dari sumber eksternal sehingga keuntungan yang dihasilkan bisa maksimal.

Kebijakan investasi berhubungan dengan pendanaan. Apabila investasi sebagian besar didanai dengan pendanaan internal maka akan mempengaruhi besarnya dividen yang dibagikan. Semakin besar investasi maka semakin berkurang dividen yang dibagikan. Apabila dana pendanaan internal kurang mencukupi dari dana yang dibutuhkan untuk investasi maka bisa dipenuhi dari eksternal khususnya dari utang.

Perusahaan yang cenderung menggunakan sumber dana eksternal untuk mendanai tambahan investasi akan membagikan dividen yang lebih besar. Untuk itulah manajer harus dapat menentukan kebijakan dividen yang memberikan keuntungan kepada investor, sedangkan di sisi lain manajer harus menjalankan perusahaan dengan tingkat pertumbuhan yang diharapkan. Pembagian dividen bertujuan untuk memaksimumkan kemakmuran pemegang saham atau nilai perusahaan yang ditunjukkan dengan nilai saham. Untuk mencapai tujuan tersebut melibatkan dua pihak yang berkepentingan dalam pembagian dividen yaitu investor dan emiten.

Dari sisi investor, dividen merupakan salah satu penyebab timbulnya motivasi investor menanamkan dananya di pasar modal. Informasi yang dimiliki investor di pasar modal sangat terbatas, maka perubahan dividen yang akan dijadikan sebagai sinyal untuk mengetahui performance perusahaan, sehingga perusahaan sering menggunakan pengumuman dividen untuk menaikkan harga saham. 
Dari sisi emiten, sangat penting untuk menentukan apakah sebagian keuntungan yang dimiliki oleh perusahaan akan lebih banyak digunakan untuk membayar dividen dibandingkan dengan retained earning atau sebaliknya. Penentuan pembagian pendapatan antara penggunaan pendapatan untuk dibayarkan kepada para pemegang saham sebagai dividen atau untuk digunakan di dalam perusahaan disebut dengan politik dividen atau kebijakan dividen.

Jika perusahaan ingin menahan sebagian besar dari pendapatannya tetap di dalam perusahaan, berarti bahwa bagian dari pendapatan yang tersedia untuk pembayaran dividen akan semakin kecil. Persentase dari pendapatan yang akan dibayarkan kepada pemegang saham sebagai cash dividen disebut dividend payout ratio. Dengan demikian dapatlah dikatakan bahwa makin tingginya dividend payout ratio yang ditetapkan oleh perusahaan maka makin kecil dana yang tersedia untuk ditanamkan kembali di dalam perusahaan yang ini berarti akan menghambat pertumbuhan perusahaan (Riyanto, 2001). Kebijakan dividen yang optimal (optimal dividend policy) ialah kebijakan dividen yang menciptakan keseimbangan diantara dividen saat ini dan pertumbuhan di masa mendatang sehingga memaksimumkan harga saham perusahaan (Brigham, 2001).

Menurut Husnan (2001) perusahaan hanya dapat membagikan dividen semakin besar jika perusahaan mampu menghasilkan laba yang semakin besar, jika laba yang dihasilkan besarnya tetap, perusahaan tidak bisa membagikan dividen yang makin besar karena perusahaan akan membagikan modal sendiri. Kebijakan dividen perusahaan tergambar pada rasio pembagian dividen yaitu persentase laba yang dibagikan dalam bentuk dividen tunai. Besar kecilnya rasio pembagian dividen akan mempengaruhi keputusan investasi para pemegang saham dan kondisi keuangan perusahaan.

Dalam maksimalisasi rasio pembagian dividen di pengaruhi oleh posisi kas. Menurut Riyanto (2001) Posisi kas atau likuiditas perusahaan merupakan faktor yang penting yang harus dipertimbangkan sebelum mengambil keputusan untuk menetapkan besarnya dividen yang akan dibayarkan kepada para pemegang saham. Oleh karena dividen merupakan arus kas keluar (cash 
outflow), maka makin kuat posisi kas perusahaan, berarti makin besar kemampuan perusahaan untuk membayar dividen.

Sudarsi (2002) menyatakan bahwa posisi kas merupakan rasio kas akhir tahun dengan pendapatan setelah pajak. Bagi perusahaan yang memiliki posisi kas yang semakin kuat akan semakin besar kemampuannya untuk membayar dividen. Faktor ini merupakan faktor internal yang dapat dikendalikan oleh manajemen sehingga pengaruhnya dapat dirasakan secara langsung bagi kebijakan dividen.

Selain itu, rasio utang terhadap ekuitas juga memiliki peranan penting dalam rasio pembagian dividen. Rasio utang terhadap ekuitas merupakan rasio yang digunakan untuk mengukur tingkat leverage (penggunaan utang) terhadap total shareholders' equity yang dimiliki perusahaan (Ang, 1997). Faktor ini mencerminkan kemampuan perusahaan dalam memenuhi seluruh kewajibannya yang ditunjukkan oleh beberapa bagian modal sendiri yang digunakan untuk membayar hutang. Semakin besar rasio ini menunjukkan semakin besar kewajibannya dan rasio yang semakin rendah akan menunjukkan semakin tinggi kemampuan perusahaan memenuhi kewajibannya.

Begitu pula dengan potensi pertumbuhan perusahaan, apabila perusahaan menentukan bahwa pelunasan utangnya akan diambilkan dari laba ditahan, maka perusahaan harus menahan sebagian besar dari pendapatannya untuk keperluan tersebut. Hal ini menunjukkan hanya sebagian kecil saja pendapatan yang dapat dibayarkan sebagai dividen, sehingga akan mempengaruhi rasio pembagian dividen perusahaan (Riyanto, 2001).

Perusahaan yang terdaftar di BEI tidak semuanya membagikan dividen kepada para pemegang sahamnya, baik itu dalam bentuk dividen tunai maupun dividen saham. Hal tersebut disebabkan oleh adanya pertimbanganpertimbangan yang berbeda dalam membuat keputusan kebijakan dan pembayaran dividen dalam setiap perusahaan (Marlina dan Clara, 2009). Dalam hal ini sektor manufaktur merupakan sektor yang paling banyak membagikan dividen kepada pemegang saham. 
Beberapa penelitian yang dilakukan berkenaan dengan rasio pembagian dividen menunjukkan hasil yang beragam Sudarsi (2002), tentang "Analisis faktor-faktor yang mempengaruhi rasio pembagian dividen pada industry perbankan yang listed di BEJ" diperoleh hasil bahwa cash position, profitabilitas, potensi pertumbuhan, ukuran perusahaan, dan debt to eqity ratio tidak mempunyai pengaruh terhadap rasio pembagian dividen. Penelitian yang dilakukan oleh Marlina dan Danica (2009), tentang "pengaruh cash position, debt to equity ratio dan return on assets terhadap rasio pembagian dividen pada perusahaan manufaktur yang terdaftar di bursa efek Indonesia (BEI)" diperoleh hasil bahwa cash position dan return on assets mempunyai pengaruh signifikan terhadap rasio pembagian dividen. Sedangkan debt to equity ratio tidak mempunyai pengaruh yang signifikan terhadap rasio pembagian dividen. Berdasarkan latar belakang yang telah diuraikan diatas maka perumusan masalah dalam penelitian ini adalah apakah Posisi Kas, Debt to Equity Ratio, dan Potensi Pertumbuhan, secara parsial dan simultan berpengaruh terhadap rasio pembagian dividen. Sesuai dengan perumusan masalah yang telah dijelaskan sebelumnya, maka tujuan penelitian ini adalah mengetahui pengaruh Posisi Kas, Debt to Equity Ratio, dan Potensi Pertumbuhan secara parsial dan simultan terhadap Dividend payout Ratio pada perusahaan manufaktur yang terdaftar di BEI tahun 2006-2008. Penelitian ini dibatasi hanya pada faktor-faktor yang diduga berpengaruh terhadap dividend payout ratio, yaitu: posisi kas, debt to equity ratio, dan potensi pertumbuhan. Subjek penelitian ini adalah perusahaan manufaktur yang terdaftar di BEI tahun 2006-2008.

Menurut Darmaji dan Hendy (2001: 8), dividen yaitu pembagian keuntungan yang diberikan perusahaan penerbit saham tersebut atas keuntungan yang dihasilkan. Dividen diberikan setelah mendapatkan persetujuan dari pemegang saham dalam rapat umum pemegang saham. Dengan kata lain dividen merupakan sebagian dari laba bersih yang diperoleh perusahaan dan akan dibagikan apabila perusahaan memperoleh keuntungan.

Ross (1997) dalam Suharly (2007) mendefinisikan dividen sebagai pembayaran kepada pemilik perusahaan yang diambil dari keuntungan perusahaan, baik dalam bentuk saham maupun tunai. Artinya hanya 
perusahaan yang membukukan keuntungan dapat membagikan dividen karena dividen diambil dari keuntungan perusahaan. Ikatan Akuntan Indonesia (2004), dalam PSAK No. 23 Paragraf 4 merumuskan dividen sebagai distribusi laba kepada pemegang saham sesuai dengan proporsi mereka dari jenis modal tertentu. Suharli (2007) menyatakan laba bersih perusahaan akan berdampak berupa peningkatan saldo laba (retained earnings) perusahaan. Apabila saldo laba didistribusikan kepada pemegang saham maka saldo laba akan berkurang sebesar nilai yang didistribusikan tersebut.

Menurut Suwaldiman dan Aziz (2006) dividen adalah bagian dari laba bersih yang diberikan kepada pemegang saham (pemilik modal sendiri). Laba bersih (Net Earnings) ini sering disebut sebagai: "Laba yang tersedia bagi pemegang saham biasa" (earnings available to common stockholders disingkat EAC). Selain dibagi kepada pemegang saham dalam bentuk dividen, laba bersih itu ditahan di dalam perusahaan untuk membiayai operasi selanjutnya dan disebut sebagai laba ditahan (Retained Earnings).

Prihantoro (2003) menyebutkan bahwa kebijakan terhadap pembayaran dividen merupakan keputusan yang sangat penting dalam suatu perusahaan. Kebijakan ini akan melibatkan dua pihak yang mempunyai kepentingan yang berbeda, yaitu pihak pertama para pemegang saham, dan pihak kedua perusahaan itu sendiri. Kebijakan dividen adalah kebijakan yang berhubungan dengan pembayaran dividen dan besarnya laba ditahan untuk kepentingan pihak perusahaan.

Menurut Riyanto (2001), kebijakan dividen bersangkutan dengan penentuan pembagian pendapatan (earning) antara pengunaan pendapatan untuk dibayarkan kepada para pemegang saham sebagai dividen atau untuk digunakan didalam perusahaan, yang berarti laba tersebut harus ditahan di dalam Perusahaan.

Laba ditahan (retained earning) merupakan salah satu dari sumber dana yang paling penting untuk membiayai pertumbuhan perusahaan. Sedangkan dividen merupakan aliran kas yang dibayarkan kepada para pemegang saham atau "equity investors". Setiap perusahaan selalu menginginkan adanya pertumbuhan bagi perusahaan tersebut di satu pihak dan juga dapat 
membayarkan dividen kepada para pemegang saham di lain pihak, tetapi kedua tujuan tersebut selalu bertentangan. Semakin tinggi tingkat dividen yang dibayarkan, maka semakin sedikit laba yang ditahan, dan sebagai akibatnya ialah menghambat tingkat pertumbuhan (rate of growth) dalam pendapatan dan harga sahamnya.

Persentase dari pendapatan yang akan di bayarkan kepada pemegang saham sebagai cash dividend disebut rasio pembagian dividen. Dengan demikian dapatlah dikatakan bahwa makin tingginya rasio pembagian dividen yang ditetapkan oleh perusahaan berarti makin kecil dana yang tersedia untuk ditanamkan kembali di dalam perusahaan yang ini berarti akan menghambat pertumbuhan perusahaan.

Menurut Husnan (2001), perusahaan hanya dapat membagikan dividen semakin besar jika perusahaan mampu menghasilkan laba yang semakin besar, jika laba yang dihasilkan besarnya tetap, perusahaan tidak bisa membagikan dividen yang makin besar karena hal ini berarti perusahaan akan membagikan modal sendiri. Semakin tinggi rasio pembagian dividen akan menguntungkan para investor tetapi dari pihak perusahaan akan memperlemah Internal Financial karena memperkecil laba ditahan. Tetapi sebaliknya rasio pembagian dividen semakin kecil akan merugikan investor (para pemegang saham) tetapi internal financial perusahaan akan semakin kuat.

Rasio pembagian dividen dapat diukur sebagai dividen yang dibayarkan dibagi dengan laba yang tersedia untuk pemegang saham umum. Perusahaan uang mempunyai risiko tinggi cenderung untuk membayar dividend payout ratio lebih kecil supaya nanti tidak memotong dividen jika laba yang diperoleh turun. Untuk perusahaan yang berisiko tinggi, probabilitas untuk mengalami laba yang menurun adalah tinggi (Jogiyanto, 2003).

Menurut Halim dan Hanafi (2005), rasio pembayaran dividen atau rasio pembagian dividen melihat bagian earning (pendapatan) yang dibayarkan sebagai dividen kepada investor. Bagian lain yang tidak dibagikan akan diinvestasikan kembali ke perusahaan. Perusahaan yang mempunyai tingkat pertumbuhan yang tinggi akan mempunyai rasio pembayaran dividen yang 
rendah, sebaliknya perusahaan yang tingkat pertumbuhannya rendah akan mempunyai rasio yang tinggi.

Pembayaran dividen merupakan bagian dari kebijakan dividen perusahaan. Rasio pembagian dividen merupakan perbandingan antara DPS dengan EPS, jadi perspektif yang dilihat adalah pertumbuhan dividend per share (DPS) terhadap pertumbuhan earning per share (EPS). Di dalam komponen DPS terkandung unsur dividen, jadi jika semakin besar dividen yang dibagikan maka akan semakin besar rasio pembagian dividennya. Pada umumnya saham-saham yang tercatat di BEJ membayar dividen setiap tahunnya dengan DPR antara 0\%$25 \%$, tetapi ada yang menggunakan tarif proyektif. Dividen yang terlalu besar bukan tidak diinginkan oleh investor, tetapi jika DPR lebih besar dari 25\%, dikuatirkan akan terjadi kesulitan likuiditas keuangan pada perseroan pada waktu mendatang.

Investor yang mengharapkan memperoleh capital gain akan lebih menyukai angka ratio ini yang rendah. Sebaliknya investor yang menyukai dividen, menginginkan angka ratio ini yang tinggi. Banyak perusahaan yang telah memiliki kebijakan dividen yang mantap dan tidak menginginkan terjadinya fluktuasi dividen (khususnya arah yang menurun), karena hal ini justru akan berpengaruh negatif terhadap harga saham. Dengan demikian dapat ditarik sebuah kesimpulan bahwa pengertian rasio pembagian dividen adalah kebijakan suatu perusahaan dalam menentukan besar kecilnya jumlah dividen yang dibagikan kepada investor dan dividen yang ditahan untuk membiayai operasional perusahaan.

Menurut Riyanto (2001) Posisi kas atau likuiditas perusahaan merupakan faktor yang penting yang harus dipertimbangkan sebelum mengambil keputusan untuk menetapkan besarnya dividen yang akan dibayarkan kepada para pemegang saham. Oleh karena dividen merupakan arus kas keluar, maka makin kuat posisi kas perusahaan, berarti makin besar kemampuan perusahaan untuk membayar dividen. Sudarsi (2002) menyatakan bahwa posisi kas merupakan rasio kas akhir tahun dengan pendapatan setelah pajak. Bagi perusahaan yang memiliki posisi kas yang semakin kuat akan semakin besar kemampuannya untuk membayar dividen. Faktor ini merupakan 
faktor internal yang dapat dikendalikan oleh manajemen sehingga pengaruhnya dapat dirasakan secara langsung bagi kebijakan dividen. Sunarto dan Kartika (2003) menyebutkan bahwa kebijakan dividen merupakan keputusan pembayaran dividen yang mempertimbangkan maksimalisasi harga saham saat ini dan periode mendatang.

Martono dan Harjito (2001) dalam Hakim (2006) mengutarakan bahwa kebijakan dividen merupakan keputusan apakah laba yang diperoleh perusahaan pada akhir tahun akan dibagi kepada pemegang saham dalam bentuk dividen atau akan ditahan untuk menambah modal guna pembiayaan investasi di masa yang akan datang. Martono dan Harjito melanjutkan, Rasio pembagian dividen menentukan jumlah laba dibagi dalam bentuk dividen kas dan laba yang ditahan sebagai sumber pendanaan. Rasio ini menunjukkan persentase laba perusahaan yang dibayarkan kepada pemegang saham biasa perusahaan berupa dividen kas. Apabila laba perusahaan yang ditahan dalam jumlah besar, berarti laba yang akan dibagi sebagai dividen menjadi lebih kecil.

Menurut Ang (1997) debt to equity ratio merupakan rasio yang digunakan untuk mengukur tingkat leverage (penggunaan utang) terhadap total shareholders' equity yang dimiliki perusahaan. Faktor ini mencerminkan kemampuan perusahaan dalam memenuhi seluruh kewajibannya yang ditunjukkan oleh beberapa bagian modal sendiri yang digunakan untuk membayar hutang. Semakin besar rasio ini menunjukkan semakin besar kewajibannya dan rasio yang semakin rendah akan menunjukkan semakin tinggi kemampuan perusahaan memenuhi kewajibannya.

Apabila perusahaan menentukan bahwa pelunasan utangnya akan diambilkan dari laba ditahan, berarti perusahaan harus menahan sebagian besar dari pendapatannya untuk keperluan tersebut, yang ini berarti berarti hanya sebagian kecil saja yang pendapatan yang dapat dibayarkan sebagai dividen (Riyanto, 2001). Peningkatan utang ini akan mempengaruhi tingkat pendapatan bersih yang tersedia bagi pemegang saham, artinya semakin tinggi kewajiban perusahaan, akan semakin menurunkan kemampuan perusahaan membayar dividen (Sudarsi, 2002). 
Untuk meningkatkan nilai perusahaan, di samping membuat kebijakan dividen, perusahaan dituntut untuk tumbuh. Pertumbuhan dapat diwujudkan dengan menggunakan kesempatan investasi sebaik-baiknya. Investasi berhubungan dengan pendanaan, dan apabila investasi sebagian besar didanai pendanaan internal, maka akan mempengaruhi besarnya dividen yang dibagikan, dan apabila dana pendanaan internal kurang mencukupi dari dana yang dibutuhkan untuk investasi maka bisa dipenuhinya dari eksternal khususnya dari hutang. Menurut Surasni (1998) dalam Yuniningsih (2002), perusahaan yang cenderung menggunakan sumber dana eksternal untuk mendanai tambahan investasi akan membagikan dividen yang lebih besar.

Menurut Sudarsi (2002), potensi pertumbuhan adalah potensi pertumbuhan perusahaan yang diukur dengan rasio selisih total asset pada tahun $\mathrm{t}$ dengan total asset pada tahun $\mathrm{t}-1$ terhadap total asset pada $\mathrm{t}-1$. Semakin cepat tingkat pertumbuhan perusahaan, semakin besar kebutuhan akan dana untuk membiayai perluasan perusahaan. Semakin besar kebutuhan dimasa akan datang, maka semakin mungkin perusahaan menahan pendapatan, bukan membayarkannya sebagai dividen.

Pertumbuhan perusahaan secara terus menerus adalah diperlukan agar dapat hidup dan memberi kemakmuran yang lebih tinggi kepada pemilik saham. Untuk tumbuh, perusahaan memerlukan dana yang lebih besar untuk memdanai perluasan investasinya. Dana tersebut dapat diperoleh dari dari berbagai sumber baik internal maupu eksternal. Sumber internal dapat berupa depresiasi dan laba ditahan. Sumber dana eksternal dapat berupa pinjaman dari bank atau lembaga keuangan lainnya, menjual obligasi atau menjual saham baru. Apabila perusahaan mengandalkan pendanaan investasi dengan menggunakan laba ditahan maka dividen yang dibagikan akan berkurang. Sebaliknya bila perusahaan menggunakan sumber dana eksternal maka aka nada kecenderungan membagikan dividen yang lebih besar.

\section{METODE}

Populasi yang digunakan dalam penelitian ini adalah semua perusahaan manufaktur yang selalu terdaftar di Bursa Efek Indonesia (BEI), yaitu sebanyak 83 perusahaan. Penarikan sampel yang dilakukan oleh peneliti adalah dengan 
menggunakan metode purposive sampling dimana peneliti memilih sampel berdasarkan karakteristik anggota populasi yang disesuaikan dengan maksud penelitian. Kriteria penarikan sampel yang digunakan oleh peneliti adalah (a) Perusahaan manufaktur yang selalu listing di Bursa Efek Indonesia (BEI) selama periode penelitian; (b) Perusahaan manufaktur yang selalu membagikan dividen selama periode penelitian; (c) Perusahaan manufaktur yang memiliki data laporan keuangan yang lengkap selama periode penelitian.

Metode pengumpulan data dalam penelitian ini adalah metode dokumentasi yaitu cara pengumpulan data dengan menggunakan dokumendokumen yang berhubungan dengan penelitian ini. Data atau dokumen yang digunakan dalam penelitian ini adalah Laporan Keuangan perusahaan manufaktur yang terdapat pada $w w w . i d x . c o . i d$ dan data lainnya yang diperoleh dari database Pojok Bursa Efek Indonesia.

Variabel dalam penelitian ini yaitu rasio pembagian dividen sebagai variabel dependen dan posisi kas, debt to equity ratio dan potensi pertumbuhan sebagai variabel independen. Penelitian ini menggunakan analisis regresi berganda. Analisis ini digunakan untuk mengukur kekuatan dua variabel atau lebih dan juga menunjukan arah hubungan antara variabel dependen dengan variabel independen.

Adapun rumus dari regresi linier berganda (multiple linier regresion) secara umum adalah sebagai berikut.

$$
\mathrm{Y}=\mathrm{a}+\mathrm{b}_{1} \mathrm{X}_{1}+\mathrm{b}_{2} \mathrm{X}_{2}+\mathrm{b}_{3} \mathrm{X}_{3}+\mathrm{b}_{4} \mathrm{X}_{4}+\mathrm{e}
$$

Berdasarkan mekanisme hubungan antar variabel maka formulasi matematis dalam penelitian ini adalah sebagai berikut:

$$
\mathrm{DPR}=\mathrm{a}+\mathrm{b}_{1} \mathrm{CP}+\mathrm{b}_{2} \mathrm{DER}+\mathrm{b}_{3} \mathrm{GP}+\mathrm{e}
$$

Dimana:

DPR = Earnings Per Share / Dividend Per Share

$\mathrm{CP}=$ Saldo kas akhir / laba bersih setelah pajak

DER = total hutang / total modal sendiri

$\mathrm{GP}=$ total aktiva $\mathrm{t}-$ total aktiva $\mathrm{t}-1$ / total aktiva 


\section{PEMBAHASAN}

Dari uji simultan diperoleh hasil bahwa posisi kas, debt to equity ratio dan potensi pertumbuhan secara bersama-sama tidak berpengaruh signifikan terhadap rasio pembagian dividen. Nilai $\mathrm{R}^{2}$ atau nilai koefisien determinasi sebesar 0,066 atau $6,6 \%$. Hal ini berarti $6,6 \%$ variasi dividend payout ratio bisa dijelaskan oleh variasi dari ketiga variabel bebas yaitu posisi kas, debt to equity ratio dan potensi pertumbuhan sedangkan sisanya sebesar 93,4\% dijelaskan oleh faktor-faktor lain di luar model. Dari hasil tersebut maka dapat disimpulkan bahwa secara bersama-sama faktor posisi kas, debt to equity ratio dan potensi pertumbuhan tidak dapat digunakan oleh manajemen dalam memprediksi dan menentukan kebijakan dividen.

Hasil pengujian parsial terhadap variabel posisi kas menghasilkan kesimpulan bahwa terdapat pengaruh yang signifikan dari posisi kas terhadap rasio pembagian dividen. Hasil ini tidak sesuai dengan hasil penelitian yang dilakukan oleh Sudarsi yang mempunyai hasil posisi kas tidak berpengaruh signifikan terhadap rasio pembagian dividen. Dengan demikian teori yang dinyatakan oleh Riyanto terbukti bahwa posisi kas atau likuiditas perusahaan merupakan faktor yang penting yang harus dipertimbangkan sebelum mengambil keputusan untuk menetapkan besarnya dividen yang akan dibayarkan kepada para pemegang saham. Oleh karena dividen merupakan cash outflow, maka makin kuat posisi kas perusahaan, berarti makin besar kemampuan perusahaan untuk membayar dividen.

Pengujian parsial terhadap variabel debt to equity ratio diperoleh hasil bahwa tidak terdapat pengaruh yang signifikan dari debt to equity ratio terhadap rasio pembagian dividen. Hasil dari penelitian ini konsisten dengan penelitian yang telah dilakukan Sudarsi (2002) bahwa debt to equity ratio tidak berpengaruh signifikan terhadap rasio pembagian dividen. Namun hasil ini berbeda dengan teori yang dikemukakan Gitosudarmo bahwa besar kecilnya dividen payout ratio dipengaruhi oleh kebutuhan dana untuk melunasi utang. Hasil ini menunjukan bahwa debt to equity ratio bukan merupakan faktor yang menjadikan pertimbangan dalam menentukan kebijakan dividen pada perusahaan menufaktur yang mengeluarkan dividen dan terdaftar di BEI. Hal 
ini disebabkan karena adanya teori signal yang berpendapat bahwa dividen sebagai signal oleh perusahaan yang merupakan indikasi prospek perusahaan di masa yang akan datang. Ada kecenderungan harga saham akan naik jika ada pengumuman kenaikan dividen, dan harga saham akan turun jika ada pengumuman penurunan dividen. Jika perusahaan merasa bahwa prospek di masa mendatang baik, pendapatan, aliran kas diharapkan meningkat atau diperoleh pada tingkat dimana dividen yang meningkat tersebut dibayarkan, maka perusahaan akan meningkatkan dividen. Pasar akan merespon positif pengumuman kenaikan dividen tersebut. Walaupun besarnya debt to equity ratio tinggi perusahaan bisa jadi tetap membayarkan dividen yang tinggi kepada pemegang saham agar perusahaan dianggap masih mempunyai prospek yang bagus, sehingga pemegang saham tetap menanamkan investasinya.

Pengujian parsial terhadap variabel potensi pertumbuhan diperoleh hasil bahwa tidak terdapat pengaruh yang signifikan dari potensi pertumbuhan terhadap rasio pembagian dividen. Hasil dari penelitian ini konsisten dengan penelitian yang telah dilakukan Sudarsi (2002) bahwa debt to equity ratio tidak berpengaruh signifikan terhadap rasio pembagian dividen. Namun hasil ini berbeda dengan penelitian yang dilakukan oleh Nupikso dan Nurhamida yang hasilnya bahwa potensi pertumbuhan mempunyai pengaruh yang signifikan terhadap rasio pembagian dividen.

\section{SIMPULAN}

Berdasarkan pengujian hipotesis dengan menggunakan regresi linier berganda, diperoleh hasil yaitu posisi kas secara parsial berpengaruh signifikan terhadap Dividend Payout Ratio. Sehingga hasil pengujian menunjukkan menerima hipotesis 1. Debt to Equity Ratio secara parsial tidak berpengaruh signifikan terhadap Dividend Payout Ratio. Sehingga hasil pengujian menunjukkan menolak hipotesis 2. Potensi pertumbuhan secara parsial tidak berpengaruh signifikan terhadap Dividend Payout Ratio. Sehingga hasil pengujian menunjukkan menolak hipotesis. Posisi kas, Debt to equity ratio,dan Potensi pertumbuhan secara simultan tidak berpengaruh signifikan terhadap Dividend payout ratio pada perusahaan manufaktur periode pengamatan 20062008. Dengan demikian, penelitian ini menolak hipotesis 4 secara simultan. 
Peneliti menyadari sepenuhnya, bahwa masih banyak keterbatasan dalam penelitian ini antara lain (1) pemilihan variabel yang diduga berpengaruh terhadap kebijakan dividen hanya terdiri dari tiga aspek saja (posisi kas, debt to equity ratio dan potensi pertumbuhan). Hal ini memungkinkan terabaikannya faktor lain yang justru dapat mempunyai lebih pengaruh terhadap dividend payout ratio (2) periode pengamatan yang hanya tiga tahun yaitu dari tahun 2006 sampai dengan 2008, sehingga data tidak dapat menjelaskan proyeksi kebijakan jangka panjang dan sampel yang diperoleh adalah jumlahnya terbatas. Penelitian selanjutnya perlu melihat variabel-variabel lain yang berpengaruh terhadap dividend payout ratio. Hal ini dimaksudkan agar dapat diketahui pengaruh variabel-variabel lain terhadap dividend payout ratio. Selain itu, perlu mempertimbangkan sampel penelitian yang lebih banyak dan tidak perusahaan manufaktur saja serta lebih memperpanjang periode waktu pengamatannya. Hal ini dikarenakan semakin banyak sampel penelitian, maka kemungkinan hasil yang didapatkan akan lebih baik serta penelitian selanjutnya dapat menggunakan hasil penelitian ini sebagai jembatan untuk melakukan penelitian lanjutan khususnya di bidang kajian yang sama.

\section{PUSTAKA ACUAN}

Algifari. 2000. Analisis Regresi: Teori, Kasus dan Solusi. Yogyakarta: BPFE Yogyakarta.

Brigham, E.F \& J.F. Houstan. 2001. Dasar-dasar Manajemen Keuangan. Jakarta: Salemba Empat.

Darmaji, T. \& H.M. Fakhruddin. 2001. Pasar Modal Indonesia: Pendekatan dan Tanya Jawab. Ed.1. Jakarta: Salemba Empat.

Djohanputro, B. 2004. Manajemen Risiko Korporat Terintegrasi. Jakarta: PPM. Ghozali, I. 2006. Statistik Nonparametik. Semarang: Universitas Diponegoro. Gitosudarmo, I. 2001. Manajemen Keuangan. Yogyakarta: BPFE Yogyakarta. Hakim, F.R. 2006. Analisis Faktor-faktor Yang Mempengaruhi Rasio Pembayaran Dividen Pada Perusahaan Manufaktur Yang Membagikan Dividen dan Terdaftar Di BEJ Tahun 2003-2005. (Skripsi Tidak Dipublikasikan). Semarang: Universitas Negeri Semarang. 
Hartono, J. 2000. Teori Portofolio dan Analisis Investasi. Yogyakarta: BPFE Yogyakarta.

Husnan, S. 2000. Manajemen Keuangan Teori dan Penerapan (Keputusan Jangka Panjang). Ed. 4. Yogyakarta: BPFE-Yogyakarta.

Ikatan Akuntan Indonesia. 2001. Standar Akuntansi keuangan Per 1 Oktober 2004. Jakarta: Salemba Empat.

Marlina, L. \& C. Danica. 2009. Pengaruh Cash Position, Debt To Equity Ratio, dan Return On Assets Terhadap Dividend Payout Ratio. Jurnal Manajemen bisnis vol 2. No. 1. Januari: 1-6.

Nugroho, R. 2006. Pengaruh Pengumuman Dividen Terhadap Return Saham. (Skripsi Tidak Dipublikasikan). Yogyakarta: Universitas Islam Indonesia.

Nupikso, G. \& H. Nurhamida. 2002. Faktor-faktor yang Mempengaruhi Dividend Payout Ratio Pada perusahaan Manufaktur yang Terdaftar di BEJ. (Laporan Penelitian Tidak Dipublikasikan). Jakarta: Fakultas Ekonomi Universitas Terbuka.

Prihantoro. 2003. Estimasi Pengaruh Dividend Payout Ratio Pada Perusahaan Publik di Indonesia. Jurnal Ekonomi dan Bisnis Vol.8. No.1.

Putu, A.M \& Jogiyanto. 2002. Uji Teori Keagenan Dalam Hubungan Interpendensi Antara Kebijakan Hutang Dengan Kebijakan Dividen. Makalah Seminar Simposium Nasional Akuntansi V Ikatan Akuntan Indonesia.

Riyanto, B. 2001. Dasar-Dasar Pembelanjaan Perusahaan. Yogyakarta: BPFE Yogyakarta.

Sudarsi, S. 2002. Analisis Faktor-Faktor Yang Mempengaruhi Divident Payout Ratio pada Industri Perbankan yang Listed Di Bursa Efek Jakarta (BEJ). Jurnal Bisnis dan Ekonomi. Vol.9, No.1, Maret. Hal: 76-88

Suharli \& M. Oktorina. 2005. Memprediksi Tingkat Pengenbalian Investasi Pada Equity Securities Melalui Rasio Profitabilitas, Likuiditas, dan Hutang Pada Perusahaan Publik di Jakarta. Kumpulan Makalah Simposium Nasional Akuntansi 8. Solo.

Sunarto \& A. Kartika. 2003. Analisis Faktor-Faktor yang Mempengaruhi Dividen Kas di Bursa Efek Jakarta. Jurnal Bisnis dan Ekonomi. Vol.10, No.1, Maret. Hal. 67-82. 
Sutrisno. 2001. Analisis Faktor-faktor yang Mempengaruhi Dividend Payout Ratio Pada Perusahaan Publik di Indonesia. TEMA Vol 11. Maret.

Suwaldiman \& A. Aziz. 2006. Pengaruh Insider Ownership dan Risiko Pasar Terhadap kebijakan Dividen. SINERGI Vol. 8. No. 1. Januari.

Yuniningsih. 2002. Interpendensi Antara Kebijakan Dividend Payout Ratio, Financial Leverage, dan Investasi pada Perusahaan Manufaktur yang Listed di Bursa Efek Jakarta. Jurnal Bisnis dan Ekonomi, Vol.9,No.2, September: Hal. 164-182. 